\title{
Mitotic Spindle Assembly Checkpoint Protein MAD2B
}

National Cancer Institute

\section{Source}

National Cancer Institute. Mitotic Spindle Assembly Checkpoint Protein MAD2B. NCI

Thesaurus. Code C116592.

Mitotic spindle assembly checkpoint protein MAD2B (211 aa, $\sim 24 \mathrm{kDa}$ ) is encoded by the human MAD2L2 gene. This protein plays a role in DNA repair and the mitotic spindle assembly checkpoint. 